\title{
The sociology of education as the history of the present: fabrication, difference and abjection $^{1}$
}

Thomas Popkewitz ${ }^{2}$

\begin{abstract}
The paper explores the fabrications of human kinds in pedagogical research. It examines the social and psychological sciences of education as producing independent spaces for the study of people in order to act on them and as a cultural thesis for people to act for themselves. Further, it explores the principles generated about who the child is and should be. It is argued that the making of human kinds embodies particular historically generated modes of representing the possibilities of life; and these modes function to divide, differentiate and abject particular qualities of people and populations into unlivable spaces. This comparativeness produces inequality as it strives for equality. The analysis engages educational studies in a conversation with history, philosophy, political and cultural studies that draw on particular European studies brought into the US to challenge its philosophical, analytical and social/psychological traditions.
\end{abstract}

Keywords: History of present; Education sciences; Social exclusion; Abjection; Critical studies.

\section{A sociologia da educação como a história do presente: fabricação, diferença e abjeção}

\section{Resumo}

$\mathrm{O}$ artigo explora as fabricações dos sujeitos humanos na pesquisa pedagógica. Examina as Ciências Sociais e a Psicologia da Educação como produtoras de espaços independentes para o estudo das pessoas, a fim de atuar sobre elas, funcionando como uma tese cultural de modo a incitar as pessoas a agirem por si mesmas. Além disso, explora os princípios geradores do que é ser criança e como deveria ser. Argumenta-se que a produção de tipos humanos incorpora modos particulares gerados historicamente de representar as possibilidades da vida; e esses modos funcionam para dividir, diferenciar e abjetar qualidades particulares de pessoas e populações para dentro de espaços inabitáveis. Essa comparatividade produz desigualdade à medida que busca a igualdade. A análise envolve estudos educacionais em uma conversa com a história, a filosofia, os estudos políticos e culturais que se baseiam em estudos europeus específicos trazidos para os EUA para desafiar suas tradições filosóficas, analíticas e sociais/psicológicas.

Palavras-chave: História do presente; Ciências da educação; Exclusão social; Abjeção; Estudos críticos.

\section{Introduction}

This article is a study of the sciences of education. Its focus is on the human kinds that function as the autonomous subject of research in education. Youth and youth studies are such exemplars of the autonomous subject. Youth is a determinate category about a particular kind

\footnotetext{
${ }^{1}$ This article was first published on the book: Discourse: Studies in the Cultural Politics of Education. Routledge. 2012. DOI:10.1080/01596306.2012.717195, With the author and publisher consent.

2 Department of Curriculum and Instruction, University of Wisconsin, Madison, tspopkew@wisc.edu
}

Periódico Horizontes - USF - Itatiba, SP - Brasil - e019018 
of human, given an independent space to order and organize the study of schooling, crime, family and community, among others. This study is to explore the historical practices that shape and fashion the technologies that produce kinds of people, act on particular populations and functions as cultural thesis for people to act for themselves.

The first section of the article focuses on the fabrication of human kinds as a technology of governing. Fabrication has a double nuance. The autonomous subjects of research (youth, the disadvantage child) are responses to the [ontic] world by creating fictions to think about people of that world ${ }^{3}$. Fabrication is also a simultaneous manufacturing. Theories, programs and other actions are produced to ensure the 'healthy', wise and competent human kinds. Science is to identify the causes, reasons or grounds that produce the 'problems' of disaffected youth and the factors that will bring success to kinds of people through, for example, 'value-added' research about 'the effective teacher'. Research acts as agents of reform to enable the development of social programs and policy (useful knowledge) so people to act for themselves. The second section explores fabrications as determinant categories about people that embody cultural theses about modes of life. Central in this governing in liberal societies are distinctions and classifications to shape and fashion what is (and is not) human agency and participation. The third section explores the principles generated about human kinds as a comparative style of thought that differentiates and divides as part of the phenomena of inclusion. The lifelong learner is examined as a double gesture which expresses the hope of the future and simultaneously establishes human kind(s) dangerous to that future and abjected into unlivable spaces.

The approach is the History of the Present. It examines the fabrication of human kinds as formed within a grid of historical practices that makes the object of research possible to 'see' and act on. Further, the autonomous subject of research is viewed as an effect of power and political, notions that are used differently from the common sense of institutional, structural and psychological theories that focus on the actor as the origin of power. Attention is given to the political of schooling as embodied in the principles generated to intern and enclose the possibilities of what is done, thought and hoped for. The study works at the intersection of theory, history and studies of schooling and curriculum in the US and Europe. It reassembles and engages in an

\footnotetext{
${ }^{3}$ My use of ontic is to suggest that fabrication is not a social construction. It responds to things of the world and is also part of its materiality.
} 
intellectual play with French philosophy through the work of Gilles Deleuze (1964/1994), Michel Foucault (1971/1977) and lan Hacking (1986), and with studies of science and technology.

\section{The fabrication of human kinds}

I start with a general assertion and throughout the paper develop it. Fabrication is a strategy to think about the materiality of social science outside of the oppositions of text/context or theory and 'practice'. The notion has a double nuance. Adolescents, youth, at-risk, disadvantaged and the urban child are fictions. They provide a way to talk about and interpret things that are happening in the [ontic] world. The fictions about the child as a particular kind of human, however, are not merely 'ideas' to think about actions. This brings into focus the second nuance of fabrication. The subjects of research simultaneously are given the ontological status of 'real'. Theories and programs about particular kinds of people, for example, work their ways into schooling as children become those 'things - adolescents, youth, urban, at-risk and disadvantaged'! My interest in this and following sections is to consider the political of the sciences as fabrications of human kinds: practices about how to think about people, a way of acting on particular populations, and for people to act on themselves that excludes and abjects in the impulse to include.

\section{Human kinds as cultural theses about modes of living: youth}

If I begin with youth as an autonomous subject in today's policy and research, it is a determinate category that is to describe a particular subject of research. It is the stage of life which if properly planned will enable the child to become the Lifelong Learner who, if I take the distinctions in current policy and reform-oriented research, will enter successfully the Knowledge Society and 'knowledge economy'.

'Youth' is an object of study that gives ontological qualities to the child that seems seeped in biology and culture. It is the kind of human in transition between childhood and adulthood. It is someone who somehow cannot get her/his modes of living 'right' and continually gets into trouble - sexually, personally and socially. Researchers and policy-makers take as their 
responsibility to identify the 'nature' of youth, and find out how to effect changes that expiate 'youth' from their unlivable spaces. Research is given as a tool of schools, social work and parenting to enable youth to forget their transgressions and find the paths that move them into the future as productive citizens of lifelong learners.

Youth as a fabrication in research - a fiction and the making or manufacturing of things as 'real' - can be initially given attention in the making of adolescence as a category of psychology. Hall (1928) proposed adolescence as a way to respond to mass schooling, industrialization and urbanization occurring at the turn of the twentieth century. New sets of problems and challenges emerged as older traditions of schooling were no longer working and new issues of moral order were created. Adolescence was a fiction to think about the social issues. The scientific psychology, Hall argued, would identify patterns of intervention in the child's growth, development and morality that no longer seemed sufficient if left alone: "The momentum of heredity often seems insufficient to enable the child to achieve this great revolution and come to complete maturity, so that every step is strewn with wreckage of body, mind, and morals" (HALL, 1928, p.XIV).

The fiction of adolescence, however, was not merely of the researcher's 'imagination'. Adolescence became a category about people that were assumed to have independent existences and ontological qualities. Programs were installed to control the adolescent's 'proper development' and rectify moral disorders, such as sexual promiscuity and juvenile delinquency ${ }^{4}$.

One aspect of the fabrications of human kinds in social science is generating cultural theses about modes of living. Lesko (2002), for example, historically examines adolescence as theses about how children live and should live. Adolescence is, for example, the coming of age, being hormonally driven and peer orientated. The generation of cultural theses can also be identified in social science research about the Black male youth in the US. Brown (2011) argues that sociological theories speak about particular social and psychological qualities of youth that differentiate and divide the Black male from an unspoken 'other' that the Black male was not. That human kind changes over time. For example, sociological literatures envisioned the Black male as 'absent and wandering' from the 1930s to the 1950s; as 'impotent and powerless' in the

\footnotetext{
${ }^{4}$ Adolescence existed as a word previously but was inserted into the scientific psychologies at the turn of the twentieth century. It functioned as an effect of power.
} 
1960s, and then in the 1980s as the prototype 'absent father' who is powerless and has a common cultural pattern of speech and social interactions. The pathological narratives have been recently revised to stress the positive 'soulful' and 'adaptive' Black male. The positive and negative cultural theses about the Black male, Brown continues, maintain a resemblance through a populational reason. That reason normalizes a particular common sense about an independent Black male as a subject different from 'others' who are not mentioned but silently present to indicate difference.

To think of such autonomous subjects of research is to ask how such spaces are equipped; that is, made historically possible to 'see', think, act, feel and plan for. This question about its possibility, however, is not one of ideology that refers back to particular human interests that assert themselves over others. Nor is it a question of rhetoric about agents' selling their wares to convince others of the truth of what they say. My interest is historical. It is to explore the conditions that make such telling of truth possible, intelligible and actionable.

To put the question of intelligibility in its historical terms, neither St Augustine nor Confucius in their different times and places would make sense of such phrases as the Knowledge Society', the knowledge economy or the human kind called the lifelong learner who is to make the Knowledge Society possible. This observation has nothing to do with some hierarchy of wisdom or morality. Other possibilities existed about 'reason' and the self in the world. The phrases link human kinds to notions of society (lifelong learner and Knowledge Society) and social planning that were culturally, socially, institutionally and epistemologically 'not available' in the logic of St Augustine and Confucius.

At this point, the logic of this argument can be compared to Bourdieu who argues in different places about the classifications of people as historically produced and as imposing limits and producing an order' to things (BOURDIEU, 1984/1993, p.94). Bourdieu's interest, however, is to analyze differences in the use of categories and their types by exploring the conditions of their existence. The analysis maintains the structure of the subject to understand 'the poles in the field of power and the laws' that enable the functions of social unity, a tradition that draws on Durkheimian sociology. Where Bourdieuian sociology places differences in the categories and types through their relations in the field of their existence, my analysis gives focus to the grid of historical conditions through which those categories and types of defining people's 
existence are made possible as objects of thought and action ${ }^{5}$.

\section{Historicizing human kinds: grids of practices in ordering reason and making the reasonable}

person

To make the above observations about 'reason' is to focus on how 'we' think and act as a historical problem. Methodologically, it entails treating the autonomous subjects of research as events made possible and produced within a historical grid that gives intelligibility to the objects of thought and action.

The notion of grid in thinking about the fabrication of human kinds is analogous to the making of a cake. Each is formed through the mixing of different 'ingredients'. What is seen and acted on, however, are not the individual ingredients. The objects of reflection and action are historically given independent existences or an ontological status. The cake is seen as a particular class of food! Youth is what the child is on the way between childhood and adulthood!

The analogy, however, has its limits. The making of the cake involves intentionality about what ingredients to mix. Youth and the Black male are classification of people that have no single origin or essence. They are determinant classifications about the objects of thought and action made possible through different and uneven historical processes that come together in particular time/spaces. The tracking of the growth and development patterns of youth through modern large group statistics and populational reasoning, for example, is not adequately understood through some evolution of statistics as a field of human study but was made possible through different trajectories that come together in the nineteenth century that include inventions in physics, developments in statistics and the state need for a political arithmetic in which to organize people within its borders. Now this 'seeing' people through populational reasoning and statistics is part of today's common sense to organize intervention programs designed around particular human kinds, such as 'the at-risk', disadvantaged or gifted child; and in international comparisons of children's knowledge of science and mathematics to talk about national development. At the same time the notion of grid provides a way to consider the particular

\footnotetext{
${ }^{5}$ There are attempts to bring in this position via Hacking's discussion of human kinds into a Bourdieuian sociology, such as Rawolle and Lingard (2008).
}

Periódico Horizontes - USF - Itatiba, SP - Brasil - e019018 
porousness of social life and to make fragile the seemingly causality that limits the possibility of other options and alternatives.

The historicizing of human kinds as historical fabrication goes against the logic of much contemporary studies. Research inscribes identities as the origin of the 'data' from which to understand, for example, social structures and phenomenological/psychological theories of the subject. Given ontological qualities, the teacher and the child as 'youth' assume a unity and source of knowledge to understand and administer differences in the identities given expression, for example, as 'achievement gaps'.

In pedagogical research, 'the effective teacher' becomes one such determinate category about the kind of human to eliminate the dysfunctions of youth who achieve belonging to the 'achievement gap'. 'The effective teacher' is taken-for-granted in school reforms to produce 'effective teaching', to enact curriculum standards, to use learning research, and in the current econometric language of reform to provide 'the value-added' qualities instruction that solve the until-now mysteries of children's failure in school. The reforms assume the particular kinds of children as the subject of change and the site of intervention. Yet if I take research on the 'valueadded' qualities of 'the effective teacher', it is a human kind that assumes the children embodied in the unspoken values and norms of the spaces of the 'achievement gap'. That child is different from others and hence the gap. The inventions of the 'effective teacher' is a human kind in search of data that can be correlated and identified as the qualities and capabilities through which the concept is filled in (POPKEWITZ, 2011b).

The fiction of 'the effective teacher' is no longer a fiction. The 'value added' qualities are materialized as given magnitudes and correlations charted as the Teacher Profession Life Trajectories and children's achievement (DAY; SAMMONS; GU, 2008). The statistical numbers are to tell the truth about the different factors that adds 'value' to efforts to improve achievement scores and make the 'effective teacher'. The statistics, however, are not merely about value-added. It is about mode of life defined as teachers' commitment, agency, life-work management and well-being. Without going into the categories and how they embody assumptions and distinctions (such as what constitutes management and well-being), 'the value added' measures inscribe a particular kind of human designed to act on children in a world that has harmony and consensus to what is accomplished as teaching. 
The practices to intervene and calculate the life of the teacher and child are made possible through the scaffolding of different historical trajectories ${ }^{6}$. The 'effective teacher' is made possible, for example, through the intersection of the new public management about setting goals/expectations about performance (e.g. benchmarks, good practices) and econometrics among others. 'Value added' research deploys an economic language that is not about the economy in the sense of skills and knowledge necessary for the world of work. The 'value added' is directed to cultural and social practices described, for example, as student motivation, school culture and leadership, and the biography and career of the teacher. The combination of these characteristics of people and schooling are viewed as enabling student attainment and achievement.

Embodied in the notions of achievement and curriculum that circulates in the research are also re-assemblages of Northern Europe and North America enlightenments' ${ }^{7}$ hope of the cosmopolitan citizen (POPKEWITZ, 2008). Historically, cosmopolitanism, at one level, gave focus to individual reason and rationality as producing social and personal change in the name of human happiness, freedom and liberty. The human kinds of pedagogy were assembled and connected with Protestant (Calvinist) salvation themes about the good works of the individual and community at the turn of the twentieth century. Today the notions of participation, community and individual 'good works' are given different articulations of the enlightenments image of a cosmopolitan citizen who become the child as a lifelong learner in the new society of knowledge.

To summarize the argument, the notion of fabricating is a strategy to historicize the human kinds given autonomy as the subjects of research. Knowledge about the family, the child and the teacher are not merely 'ideas' about people but enter into and part of the materiality of the social world. What adult does not believe that growing up entails 'being' an adolescent, belonging to a community, and wanting to ensure equity through programs designed for urban

\footnotetext{
${ }^{6}$ Much of the discussion related to this observation is explored in the historicizing of cosmopolitanism as principles ordering and classifying schooling in Popkewitz (2008).

7 In a historical sense, the French, German, British and American philosophies and political theories of the long nineteenth century (uneven processes that are visible in the eighteenth century and through the turn of the twentieth century) embodied different notions about the subject of reason and rationality associated with enlightenment and the notion of the cosmopolitan citizen. Epistemologically, the different enlightenments did maintain a homology in inscribing notions of progress in social and political life, producing notions of human agency that valorized the relation of the social and individual, and making possible the calculation of the present as a method to effect the future. This is discussed in general in Cassirer (1932/1951) and Dumont (1991/1994).
} 
children? The historicizing of the fabrications of human kinds is to direct attention to the materiality of knowledge; that is, the rules and standards of reason embody historically produced principles that circulate to order reflection and action in everyday life. The principles are assembled as cultural theses that order how conclusions are drawn, rectification proposed and the fields of existence made manageable and predictable.

\section{Governing the subject: agency as calculated reason in an ordered time}

The autonomous subject of the social and education sciences is given intelligibility through different historical practices. These practices perform as a grid in which different principles come together and make possible the 'seeing' of the subject. The principles of pedagogy, for example, entail the previous cosmopolitan values about reason and rationality that connected with liberal political cultures and the secularization of religious salvation themes. In this section, two different principles in production of human kinds are discussed. One is agency, a way of thinking and ordering cosmopolitan notions of the subject as an actor whose purpose and intentionality produces change. Agency is a particular historical invention made visible in the Enlightenment about the subject. Today it is spoken about through notions of problem solving, ideas of empowerment and voice and through sovereign notions of power. Second - and embedded in the notion of agency - is the insertion of 'reason' in a regulated and irreversible time. Time as a regular notion in ordering life becomes historically visible in the long nineteenth century. It is embodied the thinking of the present through the future, such as the adolescent and society as having qualities of development, growth and progress.

The importance of the gird in thinking historically about the human kinds is that it directs attention to the thought, action and talk as not having a single origin or evolution of 'things'. It requires a historicizing of the connections, assemblies and disconnections that form the present and intern and encloses its possibilities.

\section{The calculation of reason in shaping and fashioning human 'agency'}

The autonomous subject given in research entails, at one layer, the inscriptions of human 'reason' as an agent of change. The thesis of human agency, an assumption of modern social 
theory, was a radical invention. The Medieval Church, for example, looked at 'reason' as a way for the soul to be saved by finding God and as a method to differentiate the savage. With the European and North American enlightenments, nature and human reason were separated. Human reason gave the mind an independence yet connectedness to nature through its obtaining the principles of the structure of the cosmos and enunciating them systematically (CASSIRER, 1932/1951).

The inscription of agency, paradoxically, brings together two registers normally placed in opposition: registers of freedom with registers of social administration ${ }^{8}$. Agency is a strategy that connects individuality and the social as part of the same phenomenon. Historically it is relatively easy to make visible that there is no individuality outside of norms and values shaped and fashioned about the social, at least within European enlightenment notions embodied in its modernities. Prior to the eighteenth century in Europe, for example, society was a word to describe an association or guild of people. Society later referred to anonymous forces and structures that gave organization to human life. The appearance of the notion of society coincided with notions of an individuality with an independent existence that was also in reference points related to sociality. The joining of society and individuality is evident in John Locke's political theory that connected the consciousness of the self to the knowledge gained through the experiences of society. Jean-Jacques Rousseau's notion of the social contract related government and individuality as central in determining 'the general will'. Adam Smith's notion of the invisible hand of markets gave focus to the abstract forces through which the individual pursued self interest in the promotion of the good of society.

The mutual assembly of the two registers of individuality and sociality was evident in the sociology and psychologies at the turn of the twentieth century. The sciences that emerged during the American Progressive movements were directed to The Social Question. That Question was about the conditions and moral disorder perceived in the northern cities and its populations of the poor, immigrants and racial groups ${ }^{9}$. The sciences of education were a

\footnotetext{
${ }^{8} \mathrm{My}$ focus is on the social science but the joining of these two registers is embodied in the institutionalization of welfare state and schooling as well.

${ }^{9}$ The Social Question was a central concern of American Progressivism that is often missed in educational histories. Furthermore, it embodied a Protestant Reformism that involved movements in both North America and northern Europe and England (RODGERS, 1998) and taken up in counter-enlightenment traditions of Italy and Spain as well.
} 
response to the Social Question that gave expression to the hope of rescue that embodied secular and revelatory forms of knowledge related to Protestant reformism (MCKNIGHT; TRICHE, 2011). The sciences of the city were to enlarge social experience in order to regulate the moral principles that order the subject's actions. The family, the child, the worker, the teacher were made into the autonomous subjects of research and as site of identities whose characteristics can be classified and ordered as rules and standards of reason and action. Research was to identify the causes of alcoholism, family disintegration, delinquency among youth and prostitution.

The sciences of the child were to change social conditions by changing the characteristics of the child, family and 'community'. The psychology of adolescence of G. Stanley Hall, for example, was assembled and connected to the Social Question. It embodied the hope of progressive cosmopolitan values that would develop 'reason, true morality, religion, sympathy, love, and aesthetic enjoyment' in the child (HALL, 1928, p.xiii). Hall spoke as part of the hope about the 'danger of loss' in 'our urbanized hothouse' that 'tends to ripen everything before its time' and where "[t]here is not only arrest, but perversion, at every stage, and hoodlumism, juvenile crime, and secret vice seem not only increasing, but develop in earlier years in every civilized land" (HALL, 1928, p.xiv). That hope of the future embodied double gestures. With the hope of saving the 'urban' child is the fears of that child as a danger to the future, inscribed in the phrase of "the moral loss and crisis produced by the "urbanized hothouse". The fear inscribed in the child psychology gives recognition to difference that at the same time inscribes divisions and inequality. The double gestures embodied in the 'reason' about child growth and development, however, is not merely that of the science. The principles generated are assembled in a grid that includes values of American republicanism and cosmopolitan notions about agency that connect with Protestant salvation themes about 'true morality', among others (TRÖHLER; POPKEWITZ; LABAREE, 2011).

The inscription of secular and revelatory forms of knowledge gave shape to the community sociology developed at the University of Chicago during the same time. The sociology inscribed the double gestures of hope and fear of the populations of the city. The sociology intersected with the Settlement House Movement, progressive pedagogical theories (such as that of Dewey) and the domestic sciences that were to change urban conditions by producing 
particular kinds of people ${ }^{10}$. The community sociology driven by Calvinist reformism and enlightenment notions of cosmopolitanism (re)visioned the Puritan notion of 'the city on the hill' as the nation's corporate mission to produce the transcendental, spiritual age (MCKNIGHT, 2003). Sanctity was given to community as a strategy of forming collective belonging through the intimate and communicative processes of face-to-face interactions.

The notion of community urbanized what was previously a pastoral image. The sociology transported and translated German social theories that differentiated the alienation of the abstract relations of modern society from the rural, and Lutheran inspired notions of the pastoral world. The American sociology (re)visioned the Lutheran assumptions into one that expressed an urbanized Calvinist moral order of congregationalism regulated by face-to-face interactions (Gemeinschaft) $^{11}$. Concepts about primary interactions and interpersonal/symbolic interactionism were to compensate for the abstract and anonymous conditions and qualities of industrial and urban 'society' (Gesellschaft).

The pastoral image of community was a strategy of changing urban populations. The concept of 'primary group' of Charles Horton Cooley (1909), one of the founding members of the American Sociological Society (later the American Sociological Association), and the symbolic interactionism of George Herbert Mead (1934) gave expression to human agency within the grid of practices associated with the processes of producing the American citizen and collective belonging. Cooley's concept of 'the looking glass self' instantiated a particular kind of person formed through interpersonal interactions and the perceptions of others. The primary group was to regulate individuality through the relation of primary group values (love, honesty, ambition, loyalty, kindness, hope) with social and institutional values given expression in notions of community associated with American Progressivism and Calvinist reformism. The role of primary

\footnotetext{
10 This is discussed in Popkewitz (2011a).

11 The notion of community that US social theories translated and transmogrified from the German Gemeinschaft was about culture in which the individual devotes all his care to the development of his personality - the selfcultivation associated with Bildung. The community was a holist feeling and orientation that was subordinate to political and social authorities. This disposition is comprehensible, according to Dumont (1991/1994) in relation to Lutheranism, where the individualism is important as the person interested in God alone and the secularized world. The notion of community spread through pietism and as a reaction to secular Enlightenment, the French and the revolution. The synthesis of holism and individualism was in Herder to vindicate German culture against the cosmopolitanism of the Enlightenment. In the US, cosmopolitanism of the American enlightenment connected with principles of Calvinist reformism. For the Calvinist influence, see Tröhler (2011).
} 
groups (family, children's play and childrearing) was viewed as crucial for the development of the inner sense of the self and the formation of morals, sentiments and ideals. George Herbert Mead placed the mind and self as formed in social processes of communication and community. The sociologies and social psychologies were cultural thesis about particular human kinds in which agency, individuality and change were to be enacted.

\section{The sciences of schooling, governing of reason and the reasonable person}

The cosmopolitan notions of 'reason' and the reasonable person are taken-for- granted as 'the common sense' in ordering the sciences of schooling. Research assumes that the sciences of the instruction can calculate what individuals have or can be given as 'reason' in order to produce individual happiness and bring social progress. Research identifies how reason is ordered, its conditions of realization and learning, and the restraints and constraints that prevent the development of the 'reasonable person'. The child is to be rescued so as to inhabit the future as 'the reasonable' person. This task of rescue is found in discussions about children's misconceptions of science and the explanation of failure as the lack of motivation. If I take an article about eighth graders learning to generalize through mathematical modeling (JUROW, 2004), this notion of rescue of human kinds and grid in which its principles operate can be made visible. The research focuses on children learning to 'reason' through social interactions and activities. The social psychology of 'situated learning' provides the interpretive frame for describing how students think about the 'real world' through mathematical modeling (JUROW, 2004). While this research about mathematics education is thoughtful about the social context influencing children's learning, my interest is in the principles generated about the thought and acting of the subject. There is a notion of individuals as purposeful agents and actors through modeling of mathematics that is made possible in a grid of practices that is never merely about mathematics. The pedagogy expresses a mode of living in which the child's rationally ordering phenomena through learning solutions to 'real-world' problems.

The 'real world problems, however, are not things natural to the world. It is a world translated and envisioned through the norms and values that are tied to the mathematical modeling. The significance of the mathematical modeling is, at one level, related to the element

$$
\text { Periódico Horizontes - USF - Itatiba, SP - Brasil - e019018 }
$$


of the enlightenment that makes the mind (reason) as an equal agent with nature. Mathematics is to enable human agency in the pursuit of individual happiness and human progress. Cognitive psychology and notions of 'situated learning' are the technologies for governing action. What constitutes the 'real world' in the mathematics lesson of 'real world' problems embeds Calvinist notions of community and liberal theories of participation that were discussed earlier.

\section{Irreversible time in the sciences of changing and making people}

The argument to this point has focused on the practices of social science as fabricating human kinds. The significance of fabrication is to locate the epistemological principles that order the planning of the 'reason' of agency as a mode of ordering life. At this point, I want to focus on the regulation of agency in the making of human kinds as embodying a 'modern' sense of an irreversible time that can be ordered and managed.

Visible in the enlightenment was a secular time about the past/present/future as irreversible processes of development and progress. The notion of time marked the political calculations that served as a humanist project to plan for the future (KOSELLECK, 1985) ${ }^{12}$. Secular time makes possible modern historicism that traces the movement of people in different spaces across a linear temporal sequence. It also made possible the study of the interior of the child during the eighteenth century (STEEDMAN, 1995).

Regulated time was operationalized in the social sciences. It placed society and individuality in processes that could be calculated and administered by identifying the origins of events (social structures and forces) and the factors that defined causation as the origin of events by, specifying, for example, the variables of research. Biography became an object of social and personal planning to secure the future named as progress. In the regulation of individuality, the rules and standards of reason link the inner qualities of the past and present to the future psychologically and socially.

The regularized notion of time as process in ordering life can be contrasted to the 'reason'

\footnotetext{
12 The idea of progress was thought of before, but becomes visible in its 'modern' configuration related to particular cosmopolitan principles of 'reason' and rationality linked to notions of society, individuality and human interests in the organization of social change.
}

Periódico Horizontes - USF - Itatiba, SP - Brasil - e019018 
of the Greek Stoics. Reason was acts of memory that liberated one's own being. Knowing oneself meant knowing the past that is drawn from the wisdom given by the gods (FOUCAULT, 2005, p.468) ${ }^{13}$. The mind preoccupied with the future was considered as consumed by forgetting and incapable of action. Claiming knowledge of the future was hubris as the future did not exist for people but for the gods.

The 'reason' of the cosmopolitanism in American social science, in contrast, instantiated a particular linear, irreversible movement of the past/present/and future. The notion of time that emerged in Western modernity made the past as not something venerated but rather something to overcome through present 'actions' that can make the possibilities of the future. Agency was embodied in time as actions that enable progress through the use of reason (COMMAGER, 1950).

This ordering of time made possible the invention of the adolescence as a subject and object of research. G. Stanley Hall's (1928) study of adolescence spoke about youth as existing in a world of irreversible time:

Old moorings are constantly broken; adaptive plasticity to new environments somatic, economic, industrial social, oral and religious - was never so great. All this suggests that man is not a permanent type but an organism in a very active stage of evolution toward a more permanent form (p.VII).

Adolescence was a temporal process of evolution, development, growth and, with the American Hegelians, dialectics. Dewey's sanction of action ordered through 'scientific habit' was to order the future by shedding unwarranted traditions identified with dogma and ignorance. "The old culture is doomed for us because it was built upon an alliance of political and spiritual powers, an equilibrium of governing and leisure classes, which no longer exists" (DEWEY, 1929, p.501-502).

The irreversible, progressive time remains as a mainstay of contemporary studies. To return to the earlier research about student mathematical modeling, children were to study and generalize about populational changes in guppies (small fish), through organizing observations of change in sequences of time. The agency of the child was in comparing and interpreting the

\footnotetext{
${ }^{13}$ As someone who studied Greek art, I recognize that I am merging historical nuances to make general points.
} 
changes in the sequences. Time provided criteria for determining, according to the authors, what is 'sensible' in 'real-world' situations through 'opportunities for identifying patterns' of differences (JUROW, 2004, p.265-267). Differences are marked by the movement in time of a stable subject. While the overt subject of the research was mathematical modeling, what is learned is not only about the particular phenomena of the lesson. The 'learning' is about ordering 'thought' about what is possible to know.

My focus on the systems of reason should not be construed as monolithic and without debate. It is important to recognize, for example, that certain strands of contemporary research disrupt notions of time as the continuous and regularized movement of past/present/future. The French historical school of the Annales, for example, engages in a notion of discontinuous time as a method of history (BRAUDEL, 1980). There are also concerns in the fluid boundaries of 'time/space' in architecture and geography (RAJCHMAN, 1997; SOJA, 1989) postmodern feminist theories about the construction of gender (STONE, 1994) and post-colonial studies. The destabilizing of the givenness of identities in the fixed space and time also finds its way in sociology, viewed as 'scapes' that consider the shifting circuits of people who animate a given social world (LESKO; TALBURT, 2011; MAIRA; SOEP, 2005). With recognition of such debates and efforts to disrupt, the task at hand is to explore the historical limits of the principles that fabricate the autonomous subject of social science research.

\section{Human kinds and the making of divisions/exclusions/abjections}

I continually have used the plural to signify the fabrication of human kinds. It is this plurality that I want to direct attention to as it embodies the political of schooling. The notion of plural is to recognize cultural theses of the self and 'others' inscribed in research through the comparative style of thought. The principles that order the 'the self' and 'other' embodies the system of reason that historically emerges in the enlightenments and which is reassembled and connected in the formation of the social and education sciences. If I use the earlier discussion of the adolescent, it embodies double gestures; that is, the child whose qualities and capabilities project the hope for the future and simultaneously qualities of the child feared as dangerous to that future. The comparative style of thought differentiates and divides in the impulse to include. 
The principles of reason that travel into the fabrication of human kinds are double gestures. The enlightenment notions of cosmopolitanism, for example, embodied differentiations and divisions between 'advanced' modern Europeans and their past. The lateseventeenth-century Quarrel of the Ancients and the Moderns symbolized a more general mode of thought that placed Europe as the most advanced civilization, one that superseded others that lacked the capacities, habits and abilities to reason. The universality given to 'reason' and rationality was the force of progress that acknowledged hospitality to 'others'. That acknowledgment to the 'other', however, was continually placed in a globalizing or universalizing set of values that produced hierarchies in relation to the 'self'. Those outside were placed in a continuum of value and those not seen as capable of the 'reason' of agency abjected, cast out into unlivable spaces of the 'backward' child, savage and barbaric at the turn of the twentieth century ${ }^{14}$

The historical significance is that difference is established through the ontological status as given identities. The inscription of the autonomous subject of research simultaneously generates principles about who the child is and should be; and also about the human kind targeted for remediation to correct differences. Such comparative inscriptions were embodied in the eighteenth-century French philosophers of the enlightenment who talked about creating an equal society through universalizing the qualities and characteristics of their present time/space as human 'reason', and in today's processes of universalizing and essentializing the ontologies of the present through learning psychologies and notions of Lifelong Learning that are spoken about as enabling a more human and just society.

While the commitment to a just and equal society is important, attention needs to be given to rules and standards that are historically inscribed as principles to articulate commitments to difference. To return to the discussion of G. Stanley Hall, adolescence was a double gesture of difference. Hall thought of the science of psychology as finding 'true morality', love, aesthetics and reason that was set against that kind of person who embodied the dangers of 'the urbanized hothouse' and its 'wreckage of body, mind and morals'.

The particular system of reason in the psychology of Hall, however, historically gave

\footnotetext{
${ }^{14}$ I discuss this in Popkewitz (2008).
} 
visibility to particular European and North American enlightenments referred to earlier. The comparative style of thought was assembled in early twentieth-century sociologies and psychologies of the family and childhood. The institutionalization of the social science disciplines were, in part, responses to a cross Atlantic Social Question and Protestant reforms to undo the moral disorders associated with urban life affected through migrations, immigrations and industrialization discussed earlier with the Chicago community sociology. The theories and programs of American Progressivism, for example, were directed to the 'urban' problem. Professional knowledge was the key to the planned interventions. The social sciences and reforms focused on those populations different from unspoken cosmopolitan norms and values. The immigrants from southern and eastern Europe, former African-American slaves and Chinese laborers, for example, were differentiated and divided from what was called 'the American Race', even in programs of education that recognized these populations for inclusion.

It is now possible to consider further how the system of reason that recognizes the human kinds for inclusion inscribes difference through distinctions about what it is not. If we pursue one approach to youth in Developmentally Appropriate Instruction for middle school adolescence, it entails a particular mode of living that is called the lifelong learner (MANNING, 2002). The lifelong learner is the kind of person that circulates as way of thinking about a particular cosmopolitanism in contemporary policy and research. The cultural thesis of the lifelong learner is about an individual who thinks through high levels of abstractions, participating in the neverending processes of making choices, innovation and collaboration (FEJES; NICOLL, 2007; POPKEWITZ, 2008). The agency of the lifelong learner is a life of choices that maximize happiness through the continual processes of planning and working collaboratively in communities. The lifelong learner is not alone, however, but inhabits social spaces that are differentiated as the Knowledge Society and the participation in the knowledge economy.

But the lifelong learner as determinant category is simultaneously differentiates and distinguishes its others as kinds of people. One does not have to go too far to find double gestures as part of the same phenomena of school reform: inscribing the kind of person who is the danger to the future in giving attention to the individuality of the child that is to be the hope of that future. A discussion about the developmentally appropriate instruction to produce the lifelong learner of the future called The Knowledge Society, for example, embodies principles about who 
is not that child and who teaches to rescue and redeem from the threats of the immorality.

The hope and fear appear as one: "Early adolescence years may be the best time to provide intervention strategies that", in the language of hope and its fears, "help youngsters avoid academic failure and behavior" (MANNING, 2002, p.52). Then that hope is followed by the fears of the young adolescent who experiments: "[...] with sexual activity, often leading to sexually transmitted diseases and early pregnancy, use of cigarettes and/or marijuana and other illicit drugs; lower school grades and dropping out, and delinquency and criminal offences" (p.52).

The double gestures of hope and fear reinscribe the 'troubled youth' as a human kind recognized for inclusion and signified as 'urban', ethnic and/or immigrant in the USA. The category of 'troubled youth' is often cast as the child who is not succeeding, psychologically troubled and socially in danger. The troubled youth is a determinate category given intelligibility in a grid of psychological distinctions about poor communication skills, poor self-concept, the lack of self-esteem and low expectations and motivation. The psychological distinctions overlap with socio-logical characteristics of poverty, socially disadvantaged, broken families or single parent households and what is called 'fragile' and 'dysfunctional families'. Research is to identify the conditions (social and psychological) that produce the troubled person and the 'practical knowledge' for policy-makers, programs, school leaders and teachers to rectify the conditions and eliminate their exclusions. The difficulty in the recognition of exclusion is that it embodied the child as different. The representation and identities of the 'urban', disadvantaged and immigrant human kinds to be saved occupy cultural spaces of difference, with such differences so that they can never be 'of the average'15.

The comparative style of thought brings into focus the systems of reason in certain contemporary projects of reform in the social and education sciences. The New Public Management is one such example. The New Public Management circulates internationally to rectify inequality and promote progress through establishing benchmarks and standards that define expectations of the future. The technical notions of finding 'truth' and salvation of the public management is part of the creation and implementation of international classification and measurement of students' outcomes in TIMMS and PISA. PISA, for example, is to identify the

\footnotetext{
${ }^{15}$ The construction of difference in the name of rescuing the urban and rural child in a national teacher education reform program is discussed in Popkewitz (1998).
} 
practical knowledge about science and mathematics that children will need in the future. If I consider PISA as one expression of formulations of PISA embodies distinctions and differentiations about, for example, children's capacity to solve and interpret problems, and 'motivation to learn, their beliefs about themselves and their attitudes to what they are learning'.

My interest in PISA as an exemplar in The New Public Management is in the making of human kinds and the style of comparative thought discussed above. Before exploring this, I have to admit that there is a certain hubris in PISA about the claims of knowing the future that scientists, mathematicians and others would never claim. But along with this hubris, the categories about practical problem solving and motivation are not about the future. Nor are they merely descriptions of what children do. They are theoretical qualities from which equivalences and differences are produced to guide the measurement of conduct. This is clearer when the International standards are examined. They are not derived from empirical studies about what scientists know or the cutting edges that have possibly some relation to the future of the disciplines. Their categories of PISA (and public management in general as it relates to schooling) are formed through abstractions about the school content and learning psychologies whose classifications shape and fashion its human kinds through the empirical data collected (NORMAND, 2010; PEREYRA; KOTTOFF; COWEN, 2011).

Such benchmarks and comparison do more than measure productivity. The standards of the human kind who knows the future (or the future skills of science and mathematics) entail a double gesture of inscriptions of differences in the recognition of difference (POPKEWITZ, 2011b). The classifications and measurements are part of a grid that moves between psychological and social characteristic that place the disadvantaged, urban and immigrant youth in in-between spaces to be included and, at the same time, abjected.

The research and the political: planning people and other possibilities of enacting social commitments

In the opening paragraph I called this study a 'History of the Present'. I will now explore it through the way that the argument was approached in the previous discussion. The purpose is to make visible the rules and standards of reason that make up the sovereign subject of research. 
At first glance, there are some similarities to the history of the present with the critical study of schooling of the Frankfurt School and the Bourdieu's sociology discussed earlier ${ }^{16}$. It is critical to engage the 'common sense' of thought and action of the present and thus to make fragile the seeming causality given to social life. This discussion of the history of the present differs from the Frankfurt School and Bourdieu, however, in the loci of what constitutes the political. To be schematic with a broad field of research, Bourdieu and the Frankfurt School focus on the conditions of existence in which the actors and their representations are distributed with unequal power. The representations of the subject are given as the origin of actions, the explanations of difference, with change located in the remaking and differences of human kinds.

This study, in contrast, engages a notion of critical that explores the limits of making the subject as the source of origin of differences. This limit can be explored through taking Jacque Rancière's (1983/2004) work about the political, and placing it in relation to the fabrication of human kinds. He argues that the social sciences begin with the assumption of inequality that it is to erase. That assumption of inequality, he continues, is the starting point of research, which reinscribes a division and hierarchy that installs the expertise of the social science as the shepherd. Where Rancière reinscribes actors in a hierarchy of difference in political philosophy, my interest is in how the comparative style of thought in research instantiates conditions of inequality under the name of equality ${ }^{17}$. I have argued, for example, that the inscription of the sovereign subject in research engenders a continuum of values through which divisions are established.

There are methodological issues in the notion of history of the present about what constitutes the object of study, but as with all methods they are also more than 'mere' methods. The exploration of the making of human kinds was treated as 'an event' that could be historically interrogated. Adolescent and 'troubled youth', for example, were examined not as facts or 'data' from which to understand their performances and actions. They were studied to excavate the historical conditions that made the autonomous subjects possible and gave intelligibility to what

\footnotetext{
${ }^{16}$ French sociology in the tradition of Durkheim through Bourdieu and other contemporary (re)visioning discusses its purpose as 'critical'. See Thévenot (2011), Boltanski and Thévenot (1999). Also, see Popkewitz and Fendler (1999). ${ }^{17} \mathrm{My}$ interest in Rancière is with his analytic and historical inquiry into the relation of knowledge, equality/inequality and the political; and leave aside for the moment his normative insertions, although thought-provoking, about the non-institutionalization of democracy and the attempt toward a socialist political theory of democracy. See Rancie're's The Hatred of Democracy (2006).
} 
is thought, acted on, and hoped for. The method was to understand how the objects of reflection and action are made possible and cast as determinate categories. The principles generated embody a grid of different cultural practices that come together at particular historical time/spaces to order conduct (FOUCAULT, 2008, 2010). Historicizing, then, is not the search for origins or evolution. It is to understand how the objects of the present are given plausibility as a way of telling the truth through different historical practices. These practices are disconnected from their 'origins' and reconnected in a manner that is not merely the sum of the parts to give the present it possibilities. Further, the notion of grid is to emphasize the porousness of the present and the possibilities of change and resistance.

The method has also approached the notion of materiality that is not cast through oppositions of, for example, philosophical nominalism and realism - the former in hermeneutic and psychologies of the minds and the latter found Bourdieuian and Marxist theories. The notion of fabrication draws attention to the limits of the divisions between discourse and realism, texts (discourse and theory) and 'practices' and the 'lived experience' of children and schooling. The divisions elide the ways in which 'lived experiences' and their corollary assumption about 'useful' knowledge are not something merely for research to recuperate about what is natural in the world. The notions of useful and 'lived experiences' are dependent on the consensus about the subject as an ontological 'fact' from which to order and classify the objects seen and acted on as 'practice'. Differentiating and dichotomizing theory/practice - text and context - obscure how the knowledge of the subjects of social science - youth, immigrants - are historically instantiated as technologies to act on people, and have a materiality in constituting what is and what should be.

The observations about the limits of the making of the subject, however, do not remove the need for conditional foundations to address wrongs. To historicize and thus challenge the givenness of the subject and the inscription of a comparative style of thought re-introduces the agency and issues of change but in a different register. The current discussion of historicizing the present intellectually plays with the writings of Foucault, Deleuze, Derrida, Latour, among others. Enlightenment commitments to reason, rationality and human agency are maintained, but through registers that do not reinstall and inscribe the subject as the object and subject of change, subordinate differences to identity or embrace human kinds as subjects who embody cultural anxieties. Agency is embedded in the problematizing of the givenness of the 
autonomous subjects of research and thus to provide a possibility of resistance to what is given as 'the common sense'. If I can play with the notion of agency, historicizing and making visible the conditions that make possible the inscription of the agent is to make possible alternatives outside of the contemporary frameworks.

\section{References}

BOLTANSKI, L.; THÉVENOT, L. The sociology of critical capacity. European Journal of Social Theory, v.2, n.3, p.359-377, 1999.

BOURDIEU, P.'Youth' is just a word. In: BOURDIEU, P.Sociology in question. Trad. R. Nice. London: Sage Publications, 1984/1993, p.94-102.

BRAUDEL, F. On history. Chicago: The University of Chicago Press, 1980.

BROWN, A. Same old stories: the black male in social science and educational literature, 1930s to present. Teachers College Record, v.113, n.9, p.2047-2079, 2011.

CASSIRER, E. Philosophy of the enlightenment. Trad. FRITZ C. A. KOELLN, JAMES P. PETTERGROVE. Princeton, NJ: Princeton University Press, 1932/1951.

COMMAGER, H. S. The american mind: an interpretation of American thought and character since the 1880s. New Haven, CT: Yale University Press, 1950.

COOLEY, C. H. Social organization: a study of the larger mind. New York: Charles Scribner's Sons, 1909.

DAY, C.; SAMMONS, P.; GU, Q. Combining qualitative and quantitative methodologies in research on teachers' lives, work, and effectiveness: from integration to synergy. Educational Researcher, v.37, n.6, 2008, p.330-342.

DELEUZE, G. Difference \& repetition. Trad. Paul Patton. New York: Columbia University Press, $1964 / 1994$.

DEWEY, J. The sources of a science of education. New York: Horace Liveright, 1929.

DUMONT, L. German ideology: from France to Germany and back. Chicago: The University of Chicago Press, 1991/1994.

FEJES, A.; NICOLL, K. Foucault and lifelong learning: governing the subject. London: Routledge, 2007.

Periódico Horizontes - USF - Itatiba, SP - Brasil - e019018 
FOUCAULT, M. Nietzsche, genealogy, history. In: BOUCHARD D.F. Language, counter-memory, practice: selected essays and interviews. Trad. D. F. Bouchard \& S. Simon. Ithaca, NY: Cornell University Press, 1971/1977, p.138-164.

FOUCAULT, M. The hermeneutics of the subject: lectures at the Collège de France, 1981- 1982. Trad. G. Burchell. New York: Picador, 2005.

FOUCAULT, M. The government of the self and others. lectures at the Collège de France 19821983. Trad. G. Burchell. New York: Palgrave Macmillan, 2008/2010.

HACKING, I. Making up people. In: HELLER, T. C.; SOSNA, M.; WELLBERY, D. E., Reconstructing individualism: autonomy, individuality, and the self in western thought. Stanford, CA: Stanford University Press, 1986, p.222-236 \& 347-348.

HALL, G. S. Adolescence: Its psychology and its relation to physiology, anthropology, sociology, sex, crime, religion, and education, vol.1. New York: Arno Press and The New York Times, 1928.

JUROW, A. S. Generalizing in interaction: middle school mathematics students making mathematical generalizations in a population-modeling project. Mind, Culture, and Activity, v.11, n.4, p.279-300, 2004.

KOSELLECK, R. Futures past: on the semantics of historical time. Trad. K. Tribe. Cambridge, MA: MIT Press, 1985.

LESKO, N. Act your age. the cultural construction of adolescence. New York: Routledge, 2002.

LESKO, N.; TALBURT, S. Youth studies: keywords and movement. New York: Routledge, 2011.

MAIRA, S.; SOEP, E. Youthscapes: the popular, the national, the global. Philadelphia: University of Pennsylvania, 2005.

MANNING, M. L. Developmentally appropriate middle level schools. 2. ed. Olney, MD: Association of Childhood Education International, 2002.

MCKNIGHT, D. Schooling: the puritan imperative and the molding of an american national identity. education's 'errand into the wilderness'. Mahwah, NJ: Lawrence Erlbaum, 2003.

MCKNIGHT, D.; TRICHE, S. Puritan origins of technological understanding in the USA: from William Ames's technologia to technicism. Journal of Curriculum Theorizing, v.27, n. 3, p.33-45, 2011.

MEAD, G. H. Mind, self, and society from the standpoint of a social behaviorist. Chicago: University of Chicago Press, 1934.

NORMAND, R. Expertise, networks and indicators: the construction of the European strategy in 
education. European Educational Research Journal, v.9, n.3, p.407-421, 2010.

PEREYRA, M.; KOTTOFF, H.; COWEN, R. PISA under examination: changing knowledge, changing tests, and changing schools. Rotterdam: Sense, 2011.

POPKEWITZ, T. Struggling for the soul: the politics of schooling and the construction of the teacher. New York: Teachers College Press, 1998.

POPKEWITZ, T. Cosmopolitanism and the age of school reform: science, education, and making society by making the child. New York: Routledge, 2008.

POPKEWITZ, T. From virtue as the pursuit of happiness to pursuing the unvirtuous: republicanism, cosmopolitanism, and reform protestanism in American progressive education. In: TRÖHLER, D.; POPKEWITZ, T.; LABAREE, D. F. The child, the citizen, and the promised land: comparative visions in the development of schooling in the long 19th Century. New York: Routledge, 2011a, p.291-239.

POPKEWITZ, T. Numbers in grids of intelligibility: making sense of how educational truth is told. In: H. LAUDER et al, Educating for the knowledge economy? critical perspectives. London and New York: Rouledge, 2011b, p.169-191.

POPKEWITZ, T.; FENDLER, L. Critical theories in education: changing terrains of knowledge and politics. New York: Routledge, 1999.

RAJCHMAN, J. Constructions. Cambridge, MA: MIT Press, 1997.

RANCIÈRE, J. The philosopher and his poor. Trad. J. Drury, C. Oster \& A. Parker. Durham, NC: Duke University, 1983/2004.

RANCIÈRE, J. Hatred of democracy. Trad. S. Corcoran. London: Verso, 2006.

RAWOLLE, S.; LINGARD, R. The sociology of Pierre Bourdieu and researching education policy. Journal of Education Policy, v.23, n.6, p.729-741, 2008.

RODGERS, D. T. Atlantic crossings: Social politics in a progressive age. Cambridge, MA: Belknap Press of Harvard University Press, 1998.

SOJA, E. Postmodern geographies: the reassertion of space in critical social theory. London: Verso, 1989.

STEEDMAN, C. Strange dislocations: childhood and the idea of human interiority, 1780- 1930. Cambridge, MA: Harvard University Press, 1995.

STONE, L. The education feminism reader. New York: Routledge, 1994.

$$
\text { Periódico Horizontes - USF - Itatiba, SP - Brasil - e019018 }
$$


THÉVENOT, L. Power and oppression from the perspective of the sociology of engagements: a comparison with Bourdieu's and Dewey's critical approaches to practical activities. Irish Journal of Sociology, v.19, n.1, p.35-67, 2011.

TRÖHLER, D. Languages of education: protestant legacies in educationalization of the world, national identities, and global aspirations. New York: Routledge, 2011.

TRÖHLER, D.; POPKEWITZ, T.; LABAREE, D. Schooling and the making of citizens in the long nineteenth century: comparative visions. New York: Routledge, 2011.

Recebido em outubro de 2018

Aprovado em março de 2019. 